\title{
STUDI DESKRIPTIF BIMBINGAN KARIR UNTUK KEMANDIRIAN SISWA TUNARUNGU DI SMALB
}

\author{
Meilina Juwita Andini \\ Prodi Bimbingan dan Konseling, FKIP, Universitas Darul Ulum Jombang \\ Email: meilinaokey@gmail.com
}

\begin{abstract}
Abstrak
Penelitian ini dilatarbelakangi oleh kondisi di lapangan mengenai bimbingan karir untuk kemandirian siswa tunarungu di SMALB. Bimbingan karir di SMALB adalah salah satu cara untuk membantu siswa tunarungu melatih keterampilan hidup agar mempunyai kemandirian atau pilihan kerja yang tepat saat lulus sekolah. Tujuan dari penelitian ini untuk mendeskripsikan pelaksanaan bimbingan karir untuk kemandirian tunarungu dan kendala yang dihadapi saat pelaksanaan bimbingan karir serta mencari solusi dari permasalahan tersebut. Pendekatan penelitian menggunakan deskriptif dengan metode kualitatif. Sumber data penelitian adalah siswa tunarungu di SMALB dan guru pembimbing. Hasil penelitian menunjukkan bahwa bimbingan karir di SMALB sudah cukup baik dengan adanya programprogram bimbingan yang siswa tunarungu mampu melatih keterampilan, sedangkan kendala dari bimbingan karir ada pada komunikasi yang terhambat serta kurangnya kerjasama dengan perusahaan atau lembaga kerja. Solusi dalam mengatasi masalah tersebut guru pembimbing menggunakan juru bahasa isyarat dan pihak sekolah mulai menjalin kerjasama dengan perusahaan maupun lembaga kerja. Kata kunci: Bimbingan karir, Siswa tunarungu
\end{abstract}

\section{PENDAHULUAN}

Hallahan \& Kauffman (1991, hlm. 266) mengemukakan bahwa orang yang tuli (a deaf person) adalah orang yang mengalami hambatan pendengaran, sehingga kesulitan dalam memproses informasi bahasa melalui pendengarannya baik ketika menggunakan alat bantu dengar maupun tidak.

Hambatan dalam ketunarunguan menimbulkan beberapa dampak, diantaranya terhambatnya komunikasi baik dalam berbicara maupun ketika menerima pembicaraan dari orang lain. Komunikasi merupakan hal yang utama untuk bersosialisasi dalam pendidikan maupun kehidupan di masyarakat. Hal ini berpengaruh terhadap kecakapan hidup tunarungu ketika sudah ada di masyarakat.

$$
\text { Menurut Ishartiwi (2017) }
$$

kecakapan hidup salah satu hal penting untuk individu dalam mempertahankan kehidupannya. Kecakapan hidup tersebut harus dikembangkan secara terus-menerus. Depdiknas (2007) mengemukakan bahwa kecapakan hidup dibagi dua yang pertama, General life skills (GLS) sendiri terdiri dari dua kecakapan menjadi kecakapan personal dalam mengenal diri sendiri dan kecakapan sosial. Kedua yaitu Specific life skills (SLS), yang terdiri dari kecakapan akademik dan kecakapan vokasional. Anak tunarungu diharapkan tidak hanya mengembangkan kemampuan dalam bidang akademik tetapi juga dalam kecakapan hidup. Potensi-potensi yang 
ada pada diri anak tunarungu dikembangkan sehingga mampu membantu anak tunarungu untuk kehidupan di kemudian hari. Kecakapan hidup yang sudah diperoleh berguna untuk membantu kemandirian anak tunarungu ketika selesai dari sekolah. Beberapa hal yang telah di implementasikan di sekolah yaitu bimbingan karir, dimana mampu membantu anak tunarungu untuk mengembangkan ketrampilannya. Ketrampilan yang dibutuhkan tunarungu bukan hanya menciptakan suatu karya tetapi diharapkan karya tersebut bisa mempunyai nilai jual di masyarakat

\section{Gani (2012) menyatakan}

bimbingan karir adalah sebuah layanan atau bantuan terhadap seseorang agar mampu dalam mengenal dan memahami dirinya sendiri serta merencanakan masa depannya. Selain itu bimbingan karir juga membantu seseorang untuk menentukan pilihan hidup dan membuat keputusan yang tepat untuk pekerjaanya. Sehingga mampu dalam hidup secara mandiri tanpa bergantung kepada orang lain.

Clark (1979) menyatakan ada beberapa program yang harus dilakukan yaitu pertama latihan dan bimbingan untuk mengembangkan sikap positif dan nilai kerja dalam kehidupan sehari-hari. Kedua, latihan dan bimbingan dalam bersosialisasi dengan keluarga maupun masyarakat. Ketiga, latihan dan bimbingan dalam kesadaran akan pekerjaan. Selanjutnya yang keempat yaitu latihan atau praktik terhadap dunia kerja.
Hasil studi pendahuluan di salah satu SMALB menunjukkan bahwa bimbingan karir telah dilaksanakan dalam rangka mencapai kemandirian anak tunarungu. Bimbingan karir di sekolah tersebut sebagai salah satu upaya untuk anak tunarungu ketika sudah lulus dari sekolah. Beberapa program sudah diterapkan diantaranya latihan dan bimbingan setiap minggunya. Program bimbingan karir meliputi pembuatan batik jumput dan tata rias. Anak tunarungu bisa memilih salah satu atau kedua program tersebut dalam mengembangkan keterampilannya.

Tujuan dari penelitian ini untuk mendeskripsikan pelaksanaan bimbingan karir untuk kemandirian tunarungu dan kendala yang dihadapi saat pelaksanaan bimbingan karir serta mencari solusi dari permasalahan tersebut.

\section{METODE}

Penelitian ini menggunakan metode deskriptif yang bertujuan untuk mengungkapkan data-data yang telah didapatkan di lapangan sesuai dengan kondisi anak. Sedangkan pendekatan penelitian menggunakan kualitatif. Data tersebut berupa bimbingan karir yang telah dilaksanakan di sekolah, kendala-kendala yang dihadapi oleh siswa tunarungu maupun guru serta solusi permasalahannya.

Sumber data penelitian pertama yaitu narasumber yang terdiri dari siswa tunarungu tingkat SMALB dan guru pembimbing. Kedua, yaitu berupa kegiatan bimbingan karir untuk 
kemandirian tunarungu. ketiga, yaitu dokumen yang ada mengenai kegiatan bimbingan karir untuk kemandirian tunarungu.

Menurut Sugiyono (2010, hlm. 62) teknik penggumpulan data merupakan langkah penting dalam mendapatkan data penelitian. Teknik penggumpulan data dalam penelitian ini yaitu observasi, wawancara, dan dokumentasi. Observasi digunakan untuk menggali data mengenai pelaksanaan bimbingan karir di sekolah serta kendala yang dihadapi oleh siswa tunarungu dan guru pembimbing. Wawancara terstruktur dalam penelitian ini ditunjukkan kepada siswa tunarungu dan guru pembimbing. Menurut Sutopo (2002) wawancara adalah salah satu teknik yang digunakan untuk menggumpulkan informasi dalam penelitian. Sedangkan dokumentasi terdiri dari gambar dan catatan mengenai bimbingan karir siswa tunarungu.

$$
\text { Menurut Creswell }
$$
penggunaan teknik analisis data ada tiga langkah, yaitu reduksi data, penyajian data dan verifikasi data. Reduksi data berupa rangkuman data mengenai pelaksanaan dan kendala bimbingan karir untuk kemandirian siswa tunarungu. Selanjutnya yaitu penyajian data berupa data yang telah diambil kesimpulannya untuk merumuskan solusinya. Terakhir yaitu verifikasi data dengan cara mempelajari data yang diperoleh dari awal sampai akhir sehingga diperoleh temuan baru dalam penelitian.

\section{HASIL DAN PEMBAHASAN}

Berdasarkan hasil observasi, wawancara, dan dokumentasi di SMALB, diperoleh beberapa data sebagai berikut. Hasil observasi menunjukkan di SMALB tersebut sudah dilaksanakan bimbingan karir terhadap siswa tunarungu. Sutirna (2013, hlm. 139) menyatakan bahwa bimbingan karir merupakan kemampuan seseorang dalam memahami dunia kerja baik pemahaman terhadap dirinya sendiri maupun pemahaman dalam memilih karir. Bimbingan karir di SMALB dilakukan pendekatan secara berkelompok. Program bimbingan karir dibuat oleh guru pembimbing dan disesuaikan dengan kurikulum yang ada.

Program pertama bimbingan karir di sekolah yaitu pihak sekolah menyediakan guru pembimbing khusus atau guru keterampilan. Siswa tunarungu dibekali keterampilan bagaimana tata cara membuat lamaran pekerjaan maupun wawancara kerja. Program disusun dalam jangka waktu satu bulan dengan rincian minggu pertama dan kedua yaitu latihan membuat surat lamaran kerja 2 sedangkan minggu ketiga dan keempat yaitu latihan wawancara kerja. Selanjutnya ketika siswa tunarungu sudah memenuhi indikator penilaian dalam program yang pertama akan memasuki program yang kedua yaitu kunjungan wisata kerja ke sebuah lembaga kerja. Sejauh ini kunjungan wisata kerja yang sudah dilakukan yaitu ke tempat pembuatan batik 
jumput, salon kecantikan, dan sebuah pusat perbelanjaan. Bukti kunjungan wisata kerja dibuktikkan dengan data dokumentasi berupa video, foto dan catatan laporan dari pihak sekolah. Program yang ketiga yaitu praktik kerja di sekolah, dari ketiga kunjungan wisata kerja yang telah diimplementasikan oleh SMALB ada dua jenis pekerjaan. Pertama yaitu pembuatan batik jumput dan yang kedua tata rias. Siswa tunarungu diperbolehkan untuk memilih salah satu dari kegiatan tersebut.

Hasil dari bimbingan karir tersebut diharapkan mampu melatih kecakapan hidup siswa tunarungu. Menurut Anwar (2004, hlm. 54) kecakapan hidup merupakan kemampuan seseorang dalam berinteraksi maupun beradaptasi dengan lingkungannya, selain itu individu harus mampu memiliki kecakapan untuk mengambil keputusan, memecahkan masalah, berpikir kreatif dan membina hubungan yang baik dengan orang lain. Siswa tunarungu ketika sudah lulus dari sekolah mampu untuk mengurus atau membiaya dirinya sendiri sehingga mandiri dan tidak bergantung pada orang lain.

Berdasarkan hasil beberapa program bimbingan karir menunjukkan bahwa mampu melatih kemandirian siswa tunarungu. Salah satu program unggulannya yaitu pembuatan batik jumput. Siswa tunarungu mampu membuat batik jumput dengan baik. Siswa tunarungu mampu mengikuti proses pembuatan dari awal sampai akhir yang sesuai dengan indikator penilaian dan dibimbing oleh guru keterampilan. Guru mengajarkan pembuatan batik tersebut dengan menuliskan langkah-langkahnya terlebih dahulu kemudian baru dilaksanakan praktik secara langsung. Beberapa batik jumput yang sudah selesai dibuat telah dipasarkan ketika ada acara-acara di pameran maupun acara ketika hari disabilitas internasional. Selain itu sekolah juga membuka pemesanan batik jumput yang bisa menyesuaikan warna dan pola.

Program bimbingan karir tata rias dilakasanakan dengan cukup baik. Hal ini dibuktikkan dengan adanya guru ahli di bidang tata rias yang memberikan bimbingan kepada siswa tunarungu. Siswa tunarungu dilatih dari mulai pemilihan produk-produk kecantikan yang digunakan, kemudian cara membersihkan wajah, memilih produk kecantikan yang sesuai dengan kulit wajah sampai pada hasil akhirnya. Pengkaplikasian tata rias ada pada ketika diadakan kegiatan-kegiatan di sekolah yang memerlukan tata rias. Siswa tunarungu sudah mampu praktik secara langsung. Bahkan beberapa dari siswa tunarungu mampu membuka jasa tata rias di luar sekolah.

Berdasarkan hasil wawancara kendala-kendala yang dihadapi baik dari pihak guru pembimbing maupun siswa tunarungu yaitu pertama ada pada komunikasi. Guru pembimbing yang tidak begitu meguasai bahasa isyarat merasa kesulitan ketika harus menjelaskan beberapa materi. Siswa 
tunarungu juga mempunyai kesulitan ketika guru hanya menggunakan bahasa verbal. Menurut Moores (dalam Somad dan Herawati, 1996:26), tunarungu adalah keadaan dimana anak mengalami kehilangan pendengaran, dampaknya seseorang akan kesulitan dalam menerima proses informasi bahasa melalui pendengaran. Informasi yang ditangkap ketika menggunakan bahasa verbal hanya 25\% saja. Meskipun sudah dibantu dengan memakai tulisan tetapi ada beberapa penjelasan tetap tidak mampu dipahami oleh siswa tunarungu. Selain dalam hal bahasa kendala lain yang dihadapi belum adanya praktik kerja langsung ke suatu perusahaan.

Solusi dalam menghadapi beberapa kendala tersebut dengan menyediakan juru bahasa isyarat yang menjadi perantara komunikasi antara guru pembimbing dengan siswa tunarungu. Kemudian menjalin kerja sama dengan beberapa perusahaan dan lembaga kerja lain. Adanya praktik kerja langsung di suatu perusahaan mampu membantu siswa tunarungu mengembangkan ketrampilan maupun kepercayaan dirinya.

\section{PENUTUP}

\section{Simpulan}

Berdasarkan hasil penelitian dan pembahasan mengenai bimbingan karir untuk kemandirian siswa tunarungu diperoleh data yaitu pelaksanaan bimbingan karir di SMALB sudah cukup baik. Dibuktikan dengan adanya program-program yang telah dibuat oleh sekolah. Selain itu adanya pendampingan selama proses bimbingan oleh tenaga ahli dibidangnya masing-masing. Kemandirian siswa tunarungu dalam kemandirian ketika melaksankan praktik keterampilan yang diajarkan juga sudah cukup baik. Siswa tunarungu mampu mengikuti prosedur sesuai dengan program yang ditentukan. Siswa tunarungu juga mampu memenuhi indikatir-indikator penilaian dari program tersebut. Bahkan hasil karya dari siswa-siswa tunarungu sudah bisa diperjualbelikan kepada masyarakat luas. Di SMALB juga menerima pemesanan kain batik jumput untuk masyarakat umum. Sedangkan dalam bidang tata rias apabila ada kegiatan-kegiatan di sekolah yang memerlukan jasa rias, siswa tunarungu sudah mampu untuk menjalankannya. Beberapa siswa juga mulai menerima jasa rias di luar sekolah. Berdasarkan bimbingan karir tersebut siswa tunarungu mampu menentukan pilihan karir ketika mereka sudah lulus dari sekolah. Kendala yang dihadapi yaitu dalam komunikasi, ada tenaga ahli atau guru pembimbing yang belum begitu menguasai bahasa isyarat. Sedangkan siswa tunarungu hanya menyerap beberapa informasi saja dari komunikasi secara verbal. Selain itu belum ada praktik kerja secara langsung ke sebuah perusahaan atau lembaga kerja. Solusi dari permasalahan tersebut yang pertama ketika ada hambatan komunikasi dibantu oleh guru yang menguasai bahasa isyarat atau penjelasan 
dilakukan secara tertulis. Untuk praktik kerja secara langsung, pihak sekolah berusaha menjalin kerja sama dengan beberapa lembaga kerja.

\section{Saran}

Bagi sekolah hendaknya mengadakan fokus grup diskusi yang melibatkan guru, wali kelas maupun orang tua dalam rangka memberikan bimbingan karir yang lebih terarah dan bisa menjalin kerja sama dengan perusahaan-perusahaan yang bisa menerima keterampilan siswa tunarungu. Selain itu menyediakan juru bahasa isyarat khusus yang bisa mendampingi guru pembimbing. Sehingga komunikasi bisa terjalin dengan baik antara guru dengan siswa tunarungu.

\section{DAFTAR PUSTAKA}

Anwar. (2004). Pendidikan Kecakapan Hidup (Life Skills Education). Bandung: Alfabeta.

Clark, G.M, et.al (1990). Career Development and Transition of Education for Adolescents with Disabilities. Boston: Allyn \& Bacon

Creswell, J. (2012). Educational, Research: Planning, Conducting, and Evaluating Quantitative and Qualitative Research. Boston: Pearson

$\begin{array}{cr}\text { Depdiknas. (2007). } & \text { Konsep } \\ \text { Pengembangan } & \text { Model } \\ \text { Integrasi } & \text { Kurikulum }\end{array}$

Pendidikan Kecakapan Hidup (Pendidikan Menengah). Jakarta: Bdan Penelitian dan Pengembangan Pusat Kurikulum.

Gani, Ruslan A. (2012). Bimbingan Karier. Bandung: Angkasa.

Halllahan, D.P. \& Kauffman, J.M. (1991). Exceptionality Children Intruduction to Special Education (fifth ed). New Jersey: Prentice Hall International, Inc.

Iswari, Mega. (2007) bimbingan Konseling Anal Luar Biasa. Jakarta: Departemen Pendidikan Nasional dan Direktorat Jenderal Pendidikan Tinggi, Direktorat Ketenagakerjaan.

Sugiyono. (2012). Metode Penelitian Pendidikan. Bandung: Alfabeta.

Sutirna. (2013). Bimbingan Konseling Pendidikan Formal, Nonformal dan Informal. Yogyakarta: ANDI.

Sutopo, H.B. (2002). Metodologi Penelitian Kualitatif. Surakarta: Sebelas Maret University Press.

Somad, Permanarian dan Herawati, Tati. (1996). Ortopedagogik Anak Tunarungu. Jakarta: Departemen Pendidikan dan Kebudayaan Direktorat Jenderal Pendidikan Tinggi, Proyek Pendidikan Tenaga Guru. 